\title{
Correction to: No differences in the long- term prognosis of iris and choroidal melanomas when adjusting for tumor thickness and diameter
}

Shiva Sabazade ${ }^{1,2}$, Christina Herrspiegel ${ }^{1,2}$, Viktor Gill ${ }^{2,3}$ and Gustav Stålhammar ${ }^{1,2^{*}}$

\section{Correction to: BMC Cancer 21, 1270 (2021)}

https://doi.org/10.1186/s12885-021-09002-0

Following publication of the original article [1], the authors noticed an error in their article.

The third sentence of the Results section of the abstract: "Twenty-one (68\%), $7(16 \%)$ and $2(4 \%)$ of the iris melanomas were of the spindle, mixed and epithelioid cell types, respectively." Should be replaced with: "Twenty-one (68\%), 7 (23\%) and $3(10 \%)$ of the surgically treated iris melanomas were of the spindle, mixed and epithelioid cell types, respectively."

Similarly, the same sentence should replace the sixth sentence in the Descriptive statistics of the main text.

The numbers are correctly stated in Table 1.

\section{Author details}

${ }^{1}$ St. Erik Eye Hospital, Eugeniavägen 12, 17164 Stockholm, Sweden. ${ }^{2}$ Department of Clinical Neuroscience, Division of Eye and Vision, St. Erik Eye Hospital, Karolinska Institutet, Stockholm, Sweden. ${ }^{3}$ Department of Pathology, Västmanland Hospital Västerås, Västerås, Sweden.

Published online: 04 January 2022

\author{
Reference \\ 1. Sabazade S, Herrspiegel C, Gill V, et al. No differences in the long-term \\ prognosis of iris and choroidal melanomas when adjusting for tumor \\ thickness and diameter. BMC Cancer. 2021;21:1270. https://doi.org/10. \\ 1186/s12885-021-09002-0.
} regulation or exceeds the permitted use, you will need to obtain permission directly from the copyright holder. To view a copy of this licence, visit http://creativecommons.org/licenses/by/4.0/. The Creative Commons Public Domain Dedication waiver (http://creativeco $\mathrm{mmons}$.org/publicdomain/zero/1.0/) applies to the data made available in this article, unless otherwise stated in a credit line to the data. 